\title{
Substrate Water Content and Fertilizer Rate Affect Growth and Flowering of Potted Petunia
}

\author{
Peter Alem ${ }^{1}$, Paul A. Thomas, and Marc W. van Iersel \\ Department of Horticulture, The University of Georgia, 1111 Miller Plant \\ Sciences Building, The University of Georgia, Athens, GA 30602-7273
}

Additional index words. controlled-release fertilizer, greenhouse irrigation, Petunia $\times$ hybrida, leaching, soil moisture sensors, volumetric water content, water use

\begin{abstract}
Rising concerns over environmental impacts of excessive water and fertilizer use in the horticultural industry necessitate more efficient use of water and nutrients. Both substrate volumetric water content $(\theta)$ and fertilizer affect plant growth, but their interactive effect is poorly understood. The objective of this study was to determine the optimal fertilizer rates for petunia (Petunia $\times$ hybrida) 'Dreams White' grown at different $\theta$ levels. Petunia seedlings were grown at four levels of $\theta(0.10,0.20,0.30$, and $0.40 \mathrm{~m}^{3} \cdot \mathrm{m}^{-3}$ ) with eight different rates of controlled-release fertilizer (CRF) (Osmocote $14-14-14 ; 14 \mathrm{~N}-6.1 \mathrm{P}-11.6 \mathrm{~K}$; rates of 0 to $2.5 \mathrm{~g} / \mathrm{plant}$, equivalent to 0 to $6.25 \mathrm{~kg} \cdot \mathrm{m}^{-3}$ substrate). Shoot dry weight increased as the CRF rate increased from 0 to $1.67 \mathrm{~g} / \mathrm{plant}$ but decreased again at even higher CRF rates. The effect of CRF rate on growth was more pronounced at higher $\theta$. Leaf size doubled as the $\theta$ thresholds increased from 0.10 to $0.40 \mathrm{~m}^{3} \cdot \mathrm{m}^{-3}$. Flowering was reduced by a combination of high CRF rates (greater than $0.63 \mathrm{~g} /$ plant $)$ and high $\theta\left(0.30\right.$ and $\left.0.40 \mathrm{~m}^{3} \cdot \mathrm{m}^{-3}\right)$, indicating that optimal conditions for vegetative growth are different from those for maximal flowering. These results suggest that without leaching, high-quality petunias can be grown with lower CRF rates than commercially recommended rates.
\end{abstract}

Fertilizer and irrigation are inseparable components of ornamental plant production. Nutrient availability to the roots is dependent on $\theta$, because nutrient movement is driven by mass flow and diffusion (Nye and Tinker, 1977). Greenhouse crops are typically grown in containers with a limited amount of substrate from which water and nutrients are rapidly depleted (Rouphael et al., 2008). Thus, frequent irrigation and fertilization may be required to sustain high growth rates (Cabrera, 2005). However, this does not always improve crop quality (Zheng et al., 2004), because plant growth is not enhanced by fertilizer application above an optimum rate (van Iersel et al., 1998) and growth rates may actually decline (Dole et al., 1994; James and van Iersel, 2001) as a result of increased salinity (Kang and van Iersel, 2009; Rouphael et al., 2008). Excessive fertilization also inhibits flowering in ornamentals such as Rosa xhybrida 'Baccara' (Plaut et al., 1973) and Dianthus caryophyllus 'Santorini' (Taylor et al., 2004).

Received for publication 23 Oct. 2014. Accepted for publication $5 \mathrm{Feb} .2015$

We thank Sue Dove for technical assistance and the USDA-ARS Application Technology Research Unit (Toledo, $\mathrm{OH}$ ) for their analysis of the tissue samples. We thank Fei Liu, Adam Jaeger, and Dr. Kim Love-Myers of the University of Georgia Statistical Consulting Center for their help in analyzing the data. We gratefully acknowledge funding from the USDA-NIFA Specialty Crops Research Initiative, Award \# 2009-51181-05768.

${ }^{1}$ To whom reprint requests should be addressed; e-mail peteralem@yahoo.com.
Efficient water and nutrient management is an increasingly important aspect of greenhouse production, because excessive irrigation leads to nutrient leaching and runoff, which have serious environmental consequences. Government regulations increasingly require growers to minimize their environmental impact (Lea-Cox and Ross, 2001; Majsztrik et al., 2011). Efficient fertilizer management is also economical, because of the increasing price of fertilizer (Majsztrik et al., 2011). Furthermore, leaching compromises production efficiency by removing fertilizer from the root zone (Mikkelsen et al., 1994; Ristvey et al., 2001) and lowering nutrient use efficiency (Bilderback, 2002; Shaviv and Mikkelsen, 1993).

Controlled-release fertilizer can be used to provide plants with adequate nutrition and minimize runoff because CRFs release nutrients gradually (Broschat and Moore, 2007; Cox, 1993) and are less prone to leaching than water-soluble fertilizers (Chen et al., 2001; Hershey and Paul, 1982). However, leaching can still occur with CRFs (Broschat, 1995), because initial nutrient release rates are often high and increase as substrate temperature rises (Adams et al., 2013; Birrenkott et al., 2005; Broschat, 1996; Merhaut et al., 2006).

Timers are commonly used to control greenhouse irrigation and provide water according to a predetermined schedule. This may result in unnecessary water applications and leaching because a set irrigation volume is provided regardless of $\theta$ or plant water status. Applying irrigation water in the needed amount is especially difficult when environmental conditions, and especially light levels, fluctuate from day to day (e.g., Baille et al., 1994; Garland et al., 2012; Kim et al., 2011; O’Meara et al., 2013). Precision irrigation systems, based on realtime measurements of $\theta$, can be used instead of timer-controlled systems to maintain a consistent $\theta$ with little or no leaching (Nemali and van Iersel, 2006). The use of $\theta$ measurements to trigger irrigation can reduce water use (Chappell et al., 2013) and CRF requirements (Bayer et al., 2014) in ornamental production and could be used to control plant morphology by altering $\theta$ and fertilization rates (Groves et al., 1998).

Little is known about the interactive effects of $\theta$ and fertilization in containergrown plants. Relatively low $\theta$ and high fertilization rates increase substrate electrical conductivity (EC) and inhibit growth by imposing osmotic stress in New Guinea impatiens (Impatiens hawkeri) (Haver and Schuch, 1996). Nutrient availability may also be affected by irrigation practices, because more leaching occurs as irrigation volume increases (Lea-Cox et al., 2001). Drawing on previous studies (Alem et al., 2014; Bayer et al., 2014; Chappell et al., 2013; Nemali and van Iersel, 2006), we hypothesize that by minimizing or eliminating leaching through precision irrigation control, growers can reduce CRF application rates. The objectives of this experiment were to: 1) quantify the interactive effects of CRF rate and $\theta$ on the growth of petunia; 2) determine the optimum $\theta$ and CRF rate for the production of highquality plants without leaching, and 3 ) to quantify the effect of environmental conditions on plant water use.

\section{Materials and Methods}

Plant material and treatments. Petunia 'Dreams White' seedlings were obtained from a commercial greenhouse (Tagawa Greenhouses, Brighton, CO; 512 seedlings/ flat). Controlled-release fertilizer (Osmocote 14-14-14; 14N-6.1P-11.6K; The Scotts Co., Marysville, $\mathrm{OH})$ was incorporated at eight different rates $(0,0.21,0.42,0.63,0.83,1.25$, 1.67 or $2.50 \mathrm{~g} / \mathrm{plant} ; 1 \mathrm{~g} /$ plant is equivalent to a nitrogen rate of $0.14 \mathrm{~g} / \mathrm{plant}$ and a fertilizer rate of $\approx 2.5 \mathrm{~kg} \cdot \mathrm{m}^{-3}$ ) into a peat:perlite (80:20) substrate (Fafard 1P; Fafard, Agawam, MA; $\mathrm{pH}$ range: 5.5 to 6.5 after wetting). The substrate also contained starter nutrients, a wetting agent, and dolomitic limestone, which was the main source of magnesium and calcium for the plants. Thirty-two rectangular trays $(36 \times 24.4 \times 10 \mathrm{~cm})$ were filled with substrate after which CRF was incorporated at the eight different rates. Twenty-four uniform seedlings $(\approx 5 \mathrm{~cm}$ tall) were transplanted into each of the 32 trays and hand-watered for 1 week to allow for root establishment.

Subsequent irrigation was controlled using an automated soil moisture sensor-controlled system based on the design by Nemali and van Iersel (2006). Threshold $\theta$ levels of 0.10 , $0.20,0.30$, or $0.40 \mathrm{~m}^{3} \cdot \mathrm{m}^{-3}$ and the eight CRF treatments were assigned to the 32 trays in a factorial design. Two capacitance soil 
moisture sensors (EC-5; Decagon, Pullman, WA) were inserted diagonally into the substrate of each tray and connected to a data logger (CR10; Campbell Scientific, Logan, UT) through two multiplexers (AM16/32; Campbell Scientific). Measurements were taken every $10 \mathrm{~min}$ using a 2.5 -VDC excitation voltage supplied by the data logger. The sensors' raw voltage output was converted to $\theta$ using a substrate-specific calibration $(\theta=$ voltage $\left.\times 1.8862-0.5624, R^{2}=0.95\right)$ developed using the methodology described by Nemali et al. (2007). Whenever the average $\theta$ for an individual tray fell below the threshold $\theta$, the data logger sent a signal to a relay driver (SDM-CD16AC/DC controller; Campbell Scientific), which opened a solenoid valve (X-13551-72; Dayton Electric Co., Niles, IL) for $20 \mathrm{~s}$ to irrigate the tray through two pressure-compensating emitters (WPCJ20; Netafim USA, Fresno, $\mathrm{CA})$ and a custom-made irrigation grid, supplying $3.7 \mathrm{~mL} /$ plant during each irrigation event.

Data collection. The data logger recorded the number of irrigation events daily and the average $\theta$ for each tray every $2 \mathrm{~h}$ throughout the study. Daily and total irrigation volumes were calculated using the known volume per irrigation event. Total evapotranspiration (ET) from each tray was calculated as the sum of the total amount of irrigation water applied and the change in the amount of water in the substrate over the course of the study [total $\mathrm{ET}=$ total irrigation $+($ initial $\theta-$ final $\theta) \times$ substrate volume]. Pore water EC was determined on Days 5, 6, 7, 8, 12, 13, 14, 20, and 23 after transplanting using a handheld probe (SigmaProbe; Delta T Devices, Cambridge, U.K.). This probe measures bulk $\mathrm{EC}$, the dielectric permittivity of the substrate (a proxy for water content), and substrate temperature to calculate pore water EC (Hilhorst, 2000). Leaf chlorophyll index was measured twice on four fully expanded leaves from the upper part of the canopy of two plants per treatment using a chlorophyll meter (SPAD 502; Konica Minolta Sensing Americas, Ramsey, NJ).

At the end of the experiment (Day 23), plants were visually evaluated for flower abundance and 10 fully expanded leaves were randomly sampled from the plants in each tray and measured using a leaf area meter (LI-3100; LI-COR, Lincoln, NE). The shoots were then cut off at the substrate surface and dried in an oven for 1 week at $80{ }^{\circ} \mathrm{C}$, and dry weight was determined. Nutrient concentrations of the dried shoots were subsequently analyzed at the USDAARS Application Technology Research Unit (Toledo, $\mathrm{OH}$ ). The trays with substrate were weighed after harvesting the shoots, dried, and reweighed to gravimetrically quantify their water content. These data were compared with the final $\theta$ measurements to confirm differences in $\theta$ among the treatments. Note that both the soil moisture sensors and the gravimetric measurements measure water in the roots in addition to water held in the substrate.
Environmental conditions. Plants were grown on a bench in a glass-covered greenhouse at the University of Georgia, Athens,
GA. Temperature and relative humidity $(\mathrm{RH})$ in the greenhouse were measured every $20 \mathrm{~s}$ using a temperature and humidity probe

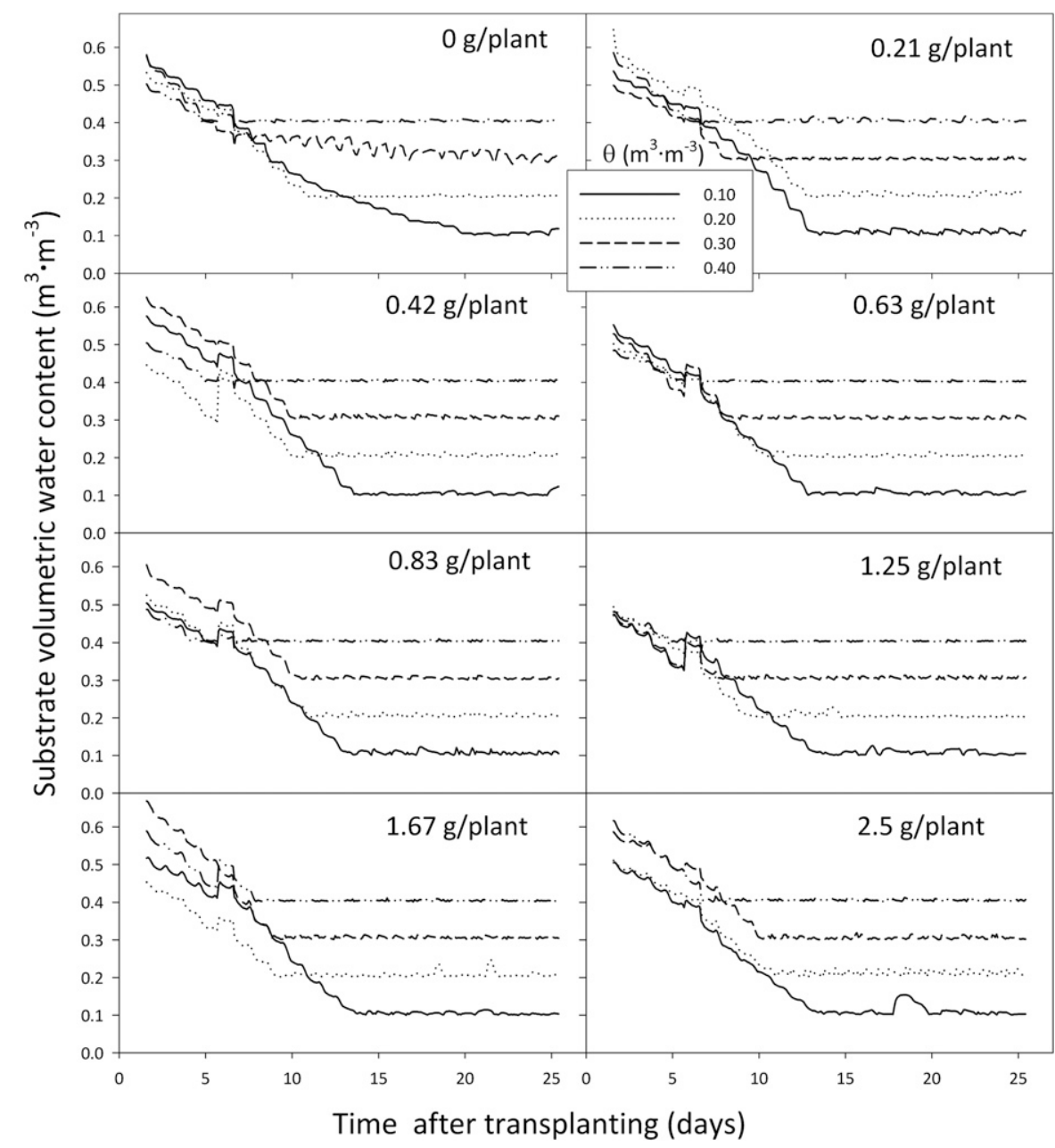

Fig. 1. The substrate volumetric water content $(\theta)$ in each treatment as maintained by a soil moisture sensor-controlled irrigation system. The values in the top right corner of each graph represent the amount of controlled release fertilizer incorporated into the substrate.

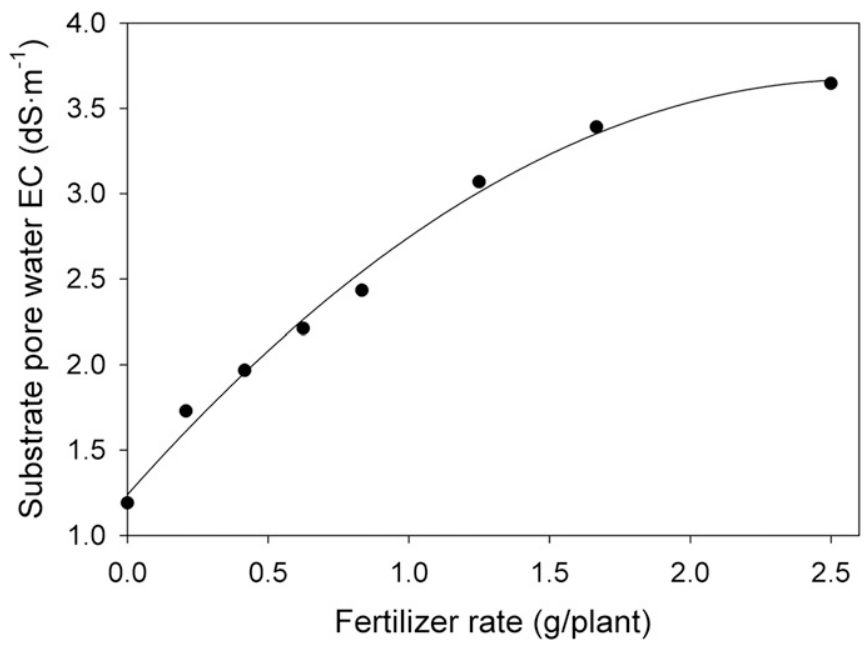

Fig. 2. Pore water electrical conductivity (EC) as a function of the amount of controlled-release fertilizer incorporated into the substrate. Each data point represents the pore water EC averaged overall four substrate water content thresholds and all 9 measurement days. Substrate water content did not affect pore water EC, whereas EC decreased over time (pore water EC $=1.56+0.0776 \times$ fertilizer rate $0.00221 \times$ day $^{2}-0.000619 \times$ fertilizer rate $\left.{ }^{2} ; R^{2}=0.77, P<0.0001\right)$. 
(HMP60; Vaisala Inc., Woburn, MA). Light [photosynthetic photon flux $(P P F)$ ] was measured using a quantum sensor (QSO-sun; Apogee Instruments, Logan, UT). All sensors were connected to the data logger, which stored daily temperature extremes and average $P P F$ and $\mathrm{RH}$ values and calculated saturation vapor pressure and vapor pressure deficit (VPD) using the temperature and $\mathrm{RH}$ data and daily light integral (DLI) from the $P P F$ data. Daily maximum and minimum temperature averaged $28.3 \pm 2.6$ and $19.0 \pm$ $2.1^{\circ} \mathrm{C}$, maximum and minimum VPD averaged $1.65 \pm 0.59$ and $0.30 \pm 0.08 \mathrm{kPa}$, whereas the DLI averaged $24.3 \pm 8.0 \mathrm{~mol} \cdot \mathrm{m}^{-2} \cdot \mathrm{d}^{-1}$ (means $\pm \mathrm{SD}$ ).

Experimental design and data analysis. The study consisted of a completely randomized factorial design with one replication of each treatment (four $\theta$ treatments $\times$ eight CRF rates). The experimental unit was a container with 24 plants. The data were subjected to multiple regression analysis using SAS (SAS Institute, Cary, NC). To quantify the effects of $\theta$ and CRF rate on the measured parameters, linear and quadratic effects of $\theta$ and CRF rate as well as the interactive effect were included in the model. For variables that were measured multiple times throughout the study, time (days after transplanting) and its interactions with $\theta$ and CRF rate were included in the model as well. Significant effects were then determined using stepwise forward selection at $P<0.05$ (proc REG; SAS Institute). We used partial $R^{2}$ values to determine how much of the variability in the data was explained by the significant components of the resulting regression model.

The effects of environmental conditions on plant water use were determined using the data from plants grown with a $\theta$ threshold of $0.40 \mathrm{~m}^{3} \cdot \mathrm{m}^{-3}$ and a CRF rate of $1.67 \mathrm{~g} /$ plant. This treatment was chosen because it produced the largest plants with the highest total irrigation volume. Stepwise forward selection regression analysis $(P<0.05$, proc REG; SAS Institute) was used to evaluate the effects of DLI, days after transplanting, average daily VPD, temperature, and their two-way interactions on daily water use.

\section{Results and Discussion}

Substrate $\theta$. Automatic irrigation commenced once the substrate dried out to below the threshold $\theta$, which took $1\left(0.40 \mathrm{~m}^{3} \cdot \mathrm{m}^{-3} \theta\right.$ threshold $)$ to 2 weeks $\left(0.10 \mathrm{~m}^{3} \cdot \mathrm{m}^{-3} \theta\right.$ threshold). Thereafter, $\theta$ was consistently maintained close to threshold levels (Fig. 1), despite changes in environmental conditions and increased transpiration rates resulting from plant growth over time, similar to previous findings (Nemali and van Iersel, 2006). Moisture sensor readings were strongly correlated to gravimetrically determined $\theta$ at the end of the study ( $r=0.94$, results not shown).

Pore water EC. Stepwise regression analysis indicated that pore water EC was unaffected by the $\theta$ threshold, whereas there was a quadratic effect of both CRF rate and time (days after transplanting). There were no significant interactions among time, CRF rate, and $\theta$ threshold (data not shown). Averaged

over the course of the study, pore water EC increased from 1.2 to $3.6 \mathrm{dS} \cdot \mathrm{m}^{-1}$ as CRF rate increased from 0 to $2.5 \mathrm{~g} /$ plant (Fig. 2).

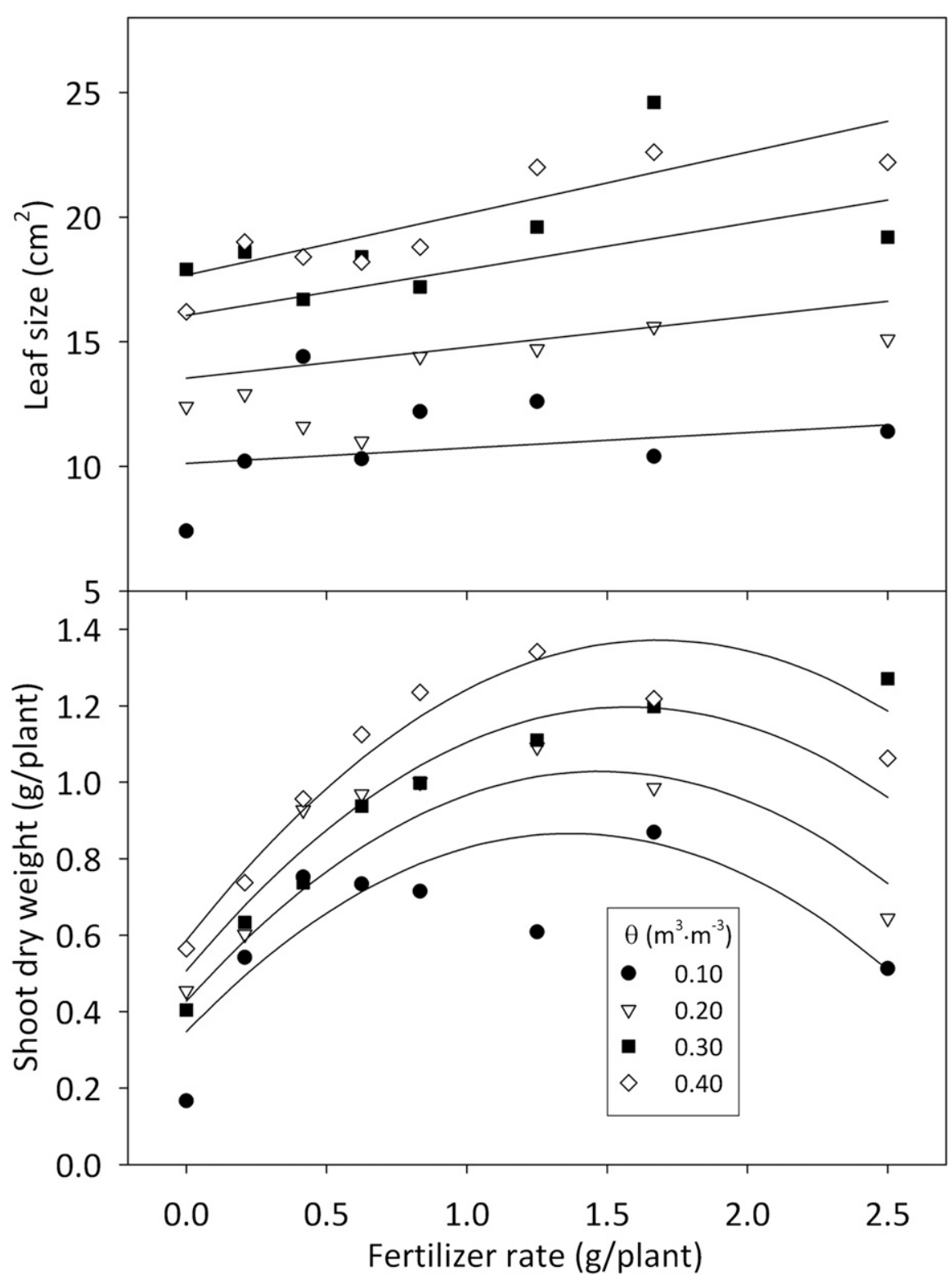

Fig. 3. Response of leaf size (area of the upper-most, fully expanded leaf) and shoot dry weight of petunias to different rates of controlled-release fertilizer at four different substrate water contents $(\theta)$. Curves indicate multiple regression results (see Table 1 for coefficients).

Table 1. Statistical analysis of the effects of substrate water content $(\theta)$ threshold and fertilizer rate on irrigation volume, shoot dry weight (DW), and leaf size. ${ }^{\mathrm{z}}$

\begin{tabular}{clcccccc}
\hline Variable & & Intercept & $\theta$ & Fertilizer & $\theta^{*}$ Fertilizer & Fertilizer $^{2}$ & Total $R^{2}$ \\
\hline Total irrigation & Coefficient & -27.980 & 714.77 & 207.56 & & -71.64 & \\
volume & $P$ & & $<0.0001$ & $<0.0003$ & $\mathrm{NS}^{\mathrm{y}}$ & 0.0242 & \\
& Partial $R^{2}$ & & 0.6049 & 0.1107 & & 0.0586 & 0.7742 \\
Shoot DW & Coefficient & 0.26846 & 0.7949 & 0.7002 & 0.584 & -0.278 & \\
& $P$ & & 0.0189 & $<0.0001$ & $<0.0001$ & 0.0010 & \\
& Partial $R^{2}$ & & 0.0360 & 0.1888 & 0.4471 & 0.1789 & 0.8508 \\
Leaf size & Coefficient & \multirow{2}{*}{8.02422} & 25.457 & & 6.064 & & \\
& $P$ & & $<0.0001$ & $\mathrm{NS}^{\mathrm{y}}$ & 0.0013 & $\mathrm{NS}^{\mathrm{y}}$ & \\
& Partial $R^{2}$ & & 0.7053 & & 0.0925 & & 0.7979 \\
\hline
\end{tabular}

${ }^{z}$ There was no quadratic effect of $\theta$ on any of the measured variables. Responses were analyzed using $y=x_{0}$ $+x_{1} \times \theta+x_{2} \times$ fertilizer $+x_{3} \times \theta \times$ fertilizer $+x_{4} \times \theta^{2}+x_{5} \times$ fertilizer $^{2}$, where $y$ is the measured variable of interest and $\mathrm{x}_{0}, \ldots, \mathrm{x}_{5}$ are regression coefficients.

${ }^{\mathrm{y}}$ Nonsignificant. 
Regardless of $\theta$ and CRF rate, pore water EC decreased by $\approx 1.2 \mathrm{dS} \cdot \mathrm{m}^{-1}$ from transplanting to the end of the experiment ( $23 \mathrm{~d}$; results not shown). Because there was no leaching, this decrease in EC was at least partly the result of plant nutrient uptake. Approximately $63 \%$ of the variation in pore water EC could be explained based on the effects of CRF rate, whereas the decrease in EC over time accounted for an additional $13 \%$ of the variation.

Pore water EC may decline with increasing $\theta$ because of dilution (Scoggins and van Iersel, 2006) or as the result of increased plant nutrient uptake attributable to faster growth. Substrate EC, determined from saturated substrate paste (Hershey, 1989), has been found to increase under low $\theta$ conditions when high rates of CRF are applied (Haver and Schuch, 1996). We observed no effect of $\theta$ on pore water EC, possibly as a result of enhanced nutrient release from the CRF at higher $\theta$ thresholds (Du et al., 2006), although Adams et al. (2013) concluded that this effect was minimal at best.

Shoot dry weight. There was a quadratic effect of CRF rate, a positive, linear effect of $\theta$, and an interactive effect of $\theta$ and CRF rate on shoot dry weight (Fig. 3; Table 1). Shoot dry weight increased as CRF rates increased from 0 to $\approx 1.67 \mathrm{~g} /$ plant at all $\theta$ thresholds and decreased again as the CRF rate increased further to $2.5 \mathrm{~g} /$ plant. Maximum shoot dry weights were achieved with CRF rates of 1.3 to $1.67 \mathrm{~g} /$ plant, corresponding to an average pore water EC of 3.1 to $3.4 \mathrm{dS} \cdot \mathrm{m}^{-1}$ (Fig. 2). The decrease in shoot dry weight at high CRF concentration was possibly caused by an increase in salt concentration in the substrate pore water (average pore water EC of $3.6 \mathrm{dS} \cdot \mathrm{m}^{-1}$ at the $2.5 \mathrm{-g} /$ plant CRF rate; Fig. 2), causing osmotic stress (Morgan and Reed, 1998). The interactive effect of $\theta$ and CRF rate on shoot dry weight indicates that increasing $\mathrm{CRF}$ rates stimulated plant growth more as the $\theta$ threshold increased. Fertilizer concentration (Frett et al., 1985; James and van Iersel, 2001) and $\theta$ threshold (Kim et al., 2011; van Iersel et al., 2010) are known to affect petunia shoot dry weight, but interactive effects have not been previously reported.

Leaf size. The area of the uppermost fully expanded leaves increased with increasing $\theta$ threshold and this effect was more pronounced at higher CRF rates (Fig. 3). Most of the variation in leaf size was explained by $\theta$ threshold (partial $R^{2}=0.71$; Table 1 ). There was a weak interactive effect of CRF rate and $\theta$ (partial $R^{2}=0.092$; Table 1$)$. Leaf size approximately doubled as the $\theta$ threshold increased from 0.10 to $0.40 \mathrm{~m}^{3} \cdot \mathrm{m}^{-3}$ (Fig. 3). A decrease in leaf expansion is among the first indicators of drought stress and is very sensitive to substrate water availability (Fernandez et al., 2002; Kalapos et al., 1996).

Shoot nutrient concentrations. There was no significant main effect of $\theta$ on shoot concentrations of any nutrient (data not shown). Shoot nitrogen (N) concentrations increased with $\mathrm{CRF}$ rate up to $\approx 1.75 \mathrm{~g} /$ plant with little response to further increases in CRF rate (Fig. 4). More than $91 \%$ of the variation in shoot $\mathrm{N}$ concentration was explained by $\mathrm{CRF}$ effects (Table 2). There was also an interactive effect of CRF rate and $\theta$ on shoot $\mathrm{N}$ concentration (Fig. 4; Table 2). Decreases in shoot $\mathrm{N}$ concentration in response to increasing $\theta$ were larger at higher CRF rates (Fig. 4). This effect was highly significant but explained only $3 \%$ of the variation in shoot $\mathrm{N}$ (Table 2) and may be the result of $\mathrm{N}$ dilution resulting from the positive effect of $\theta$ on shoot dry weight (Fig. 3).

Fertilizer rate had a quadratic effect on shoot phosphorus $(\mathrm{P})$, potassium $(\mathrm{K})$, and magnesium (Mg) concentrations (Fig. 4; Table 2), which increased with increasing

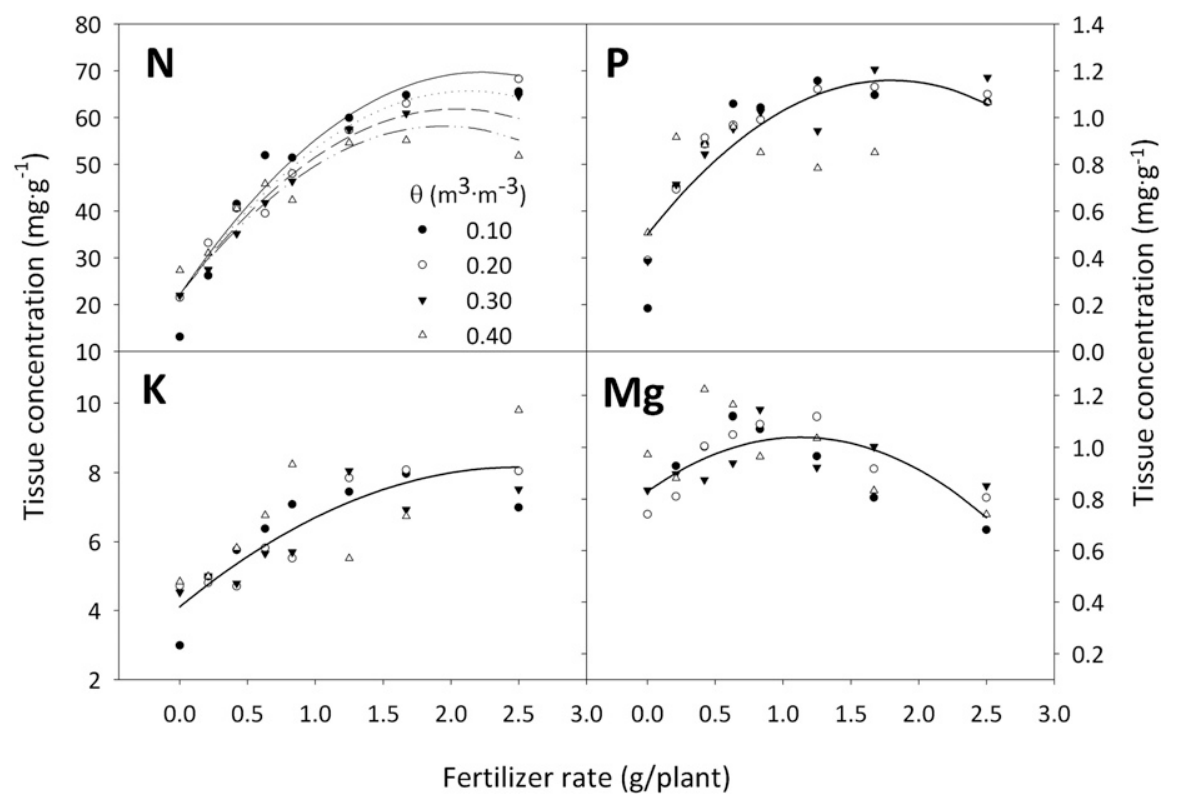

Fig. 4. Shoot nutrient concentrations of nitrogen $(\mathrm{N})$, phosphorus $(\mathrm{P})$, potassium $(\mathrm{K})$, and magnesium $(\mathrm{Mg})$ as affected by substrate volumetric water content $(\theta)$ and fertilizer rate. Symbols indicate measured tissue nutrient concentrations, whereas the curves show regression results (see Table 2 for regression equations). There was no effect of $\theta$ or interactive effect of $\theta$ and fertilizer rate on tissue $\mathrm{P}, \mathrm{K}$, and $\mathrm{Mg}$ and the regression curves for those nutrients show the quadratic effect of fertilizer rate.

Table 2. Regression coefficients, $P$ values, and $R^{2}$ values from multiple regression analysis of the effects of substrate volumetric water content $(\theta)$, fertilizer rate, and their interaction on shoot nutrient concentrations $\left(y=x_{0}+x_{1} \times \theta+x_{2} \times\right.$ fertilizer $+x_{3} \times \theta \times$ fertilizer $+x_{4} \times \theta^{2}+x_{5} \times$ Fertilizer $^{2}$, where $\mathrm{x}_{0}, \ldots, \mathrm{x}_{5}$ are regression coefficients). ${ }^{\mathrm{z}}$

\begin{tabular}{|c|c|c|c|c|c|c|}
\hline Nutrient & & Intercept & Fertilizer & $\theta *$ Fertilizer & Fertilizer $^{2}$ & Total $R^{2}$ \\
\hline \multirow[t]{3}{*}{$\mathrm{N}$} & Coefficient & 2.214 & 4.449 & -1.843 & -0.956 & \\
\hline & $P$ value & & $<0.0001$ & 0.0005 & 0.001 & \\
\hline & Partial $R^{2}$ & & 0.766 & 0.030 & 0.149 & 0.945 \\
\hline \multirow[t]{3}{*}{$\mathrm{P}$} & Coefficient & 0.5017 & 0.73392 & & -0.20477 & \\
\hline & $P$ value & & $<0.0001$ & & $<0.0001$ & \\
\hline & Partial $R^{2}$ & & 0.530 & & 0.239 & 0.769 \\
\hline \multirow[t]{3}{*}{ K } & Coefficient & 4.110 & 3.23424 & & -0.64512 & \\
\hline & $P$ value & & $<0.0001$ & & 0.0037 & \\
\hline & Partial $R^{2}$ & & 0.747 & & 0.065 & 0.812 \\
\hline \multirow[t]{3}{*}{$\mathrm{Mg}$} & Coefficient & 0.8299 & 0.35696 & & -0.16525 & \\
\hline & $P$ value & & 0.0003 & & 0.0447 & \\
\hline & Partial $R^{2}$ & & 0.318 & & 0.128 & 0.446 \\
\hline \multirow[t]{3}{*}{$\mathrm{Cu}$} & Coefficient & 3.406 & & -0.834 & & \\
\hline & $P$ value & & & 0.0421 & & \\
\hline & Partial $R^{2}$ & & & 0.131 & & 0.131 \\
\hline \multirow[t]{3}{*}{$\mathrm{Mn}$} & Coefficient & 106.9 & 20.006 & & & \\
\hline & $P$ value & & 0.0009 & & & \\
\hline & Partial $R^{2}$ & & 0.314 & & & 0.314 \\
\hline \multirow[t]{3}{*}{ B } & Coefficient & 14.78 & & & 0.599 & \\
\hline & $P$ value & & & & 0.0425 & \\
\hline & Partial $R^{2}$ & & & & 0.130 & 0.130 \\
\hline \multirow[t]{3}{*}{$\mathrm{Zn}$} & Coefficient & 67.75 & 10.008 & & & \\
\hline & $P$ value & & $<0.0001$ & & & \\
\hline & Partial $R^{2}$ & & 0.457 & & & 0.457 \\
\hline
\end{tabular}

${ }^{2}$ There was no significant effect of $\theta$ on any of the nutrients, whereas there were no significant treatment effects at all on $\mathrm{Ca}, \mathrm{S}, \mathrm{Fe}$, and $\mathrm{Mo}(P>0.05)$.

$\mathrm{N}=$ nitrogen; $\mathrm{P}=$ phosphorus $\mathrm{K}=$ potassium; $\mathrm{Mg}=$ magnesium; $\mathrm{Cu}=$ copper; $\mathrm{Mn}=$ manganese $\mathrm{B}=$ boron; $\mathrm{Zn}=$ zinc; $\mathrm{Ca}=$ calcium; $\mathrm{S}=$ sulfur; $\mathrm{Fe}=$ iron; $\mathrm{Mo}=$ molybdenum. 
fertilization rates. Higher CRF rates above $1.25 \mathrm{~g} /$ plant had little additional effect on shoot $\mathrm{P}$ and $\mathrm{K}$ concentrations. Shoot $\mathrm{Mg}$ concentrations decreased as CRF rates increased from 1.25 to $2.5 \mathrm{~g} /$ plant. The CRF did not contain $\mathrm{Mg}$ and increasing the $\mathrm{CRF}$ rate therefore did not increase the Mg supply to the plant. There was no effect of $\theta, \mathrm{CRF}$ rate, or their interaction on calcium $(\mathrm{Ca})$ and sulfur (S) concentrations (results not shown). Shoot $\mathrm{Ca}$ and $\mathrm{S}$ concentrations averaged 1.35 and $0.41 \mathrm{mg} \cdot \mathrm{g}^{-1}$, respectively.

Micronutrient shoot concentrations had no (iron and molybdenum) or a weak [zinc (Zn), boron (B), manganese (Mn), and copper $(\mathrm{Cu})]$ relationship (total $R^{2}<0.50$; Table 2) with CRF rate. There was a weak interaction of CRF rate and $\theta$ on the concentration of $\mathrm{Cu}$ in the shoot (partial $R^{2}=0.13$ ). Zinc, B, Mn, and $\mathrm{Cu}$ concentrations ranged from 61.7 to $90.1,18.0$ to $18.7,99$ to 147 , and 4.1 to $3.4 \mu \mathrm{g} \cdot \mathrm{g}^{-1}$, respectively, at CRF rates of 0 to $2.5 \mathrm{~g} / \mathrm{plant}$. The lack of strong relationships between micronutrients and CRF rate may be because the CRF contained no micronutrients. Most of the micronutrients in the plant tissue likely came from the starter fertilizer incorporated into the substrate during manufacturing. Tissue nutrient concentrations for most of the macro- and micronutrients were above the minimum of the range reported for petunia (Mills and Jones, 1996), except for the plants that did not receive CRF. The low micronutrient concentrations in the plants that did not receive CRF were surprising, because these plants received the same amount of micronutrients as those in the other treatments. This suggests that a lack of macronutrients inhibited micronutrient uptake.

Water use. Total irrigation volume was affected by $\theta$ (partial $\left.R^{2}=0.60\right)$ and CRF rate (partial $R^{2}=0.11$; Table 1). Total irrigation volume increased by $215 \mathrm{~mL} /$ plant as the irrigation $\theta$ threshold increased from 0.10 to $0.40 \mathrm{~m}^{3} \cdot \mathrm{m}^{-3}$ (Table 1; Fig. 5). Previous work with similar irrigation systems also showed an increase in total irrigation volume with an increase in $\theta$ threshold (Burnett and van Iersel, 2008; van Iersel et al., 2010). Increasing the $\mathrm{CRF}$ rate from 0 to $1.67 \mathrm{~g} / \mathrm{plant}$ increased the total irrigation volume by 91 $\mathrm{mL} /$ plant, regardless of the $\theta$ threshold. Total irrigation volume decreased slightly as the CRF rate increased from 1.67 to $2.5 \mathrm{~g} / \mathrm{plant}$ (Table 1; Fig. 5).

For the plants grown with a $0.40 \mathrm{~m}^{3} \cdot \mathrm{m}^{-3} \theta$ threshold and $1.67 \mathrm{~g} /$ plant CRF rate, most of the day-to-day variation in irrigation volume was explained by the interaction between days after transplanting (a proxy for plant age or size) and DLI $\left(R^{2}=0.96\right)$. Daily irrigation volume generally increased over time because plant size increased (Fig. 6). The effect of DLI on daily irrigation volume increased as the plants grew, because canopy light interception, which depends on DLI and canopy size, has a strong impact on plant water use (Kim et al., 2011). van Iersel et al. (2010) also reported an interactive effect of DLI and plant age on the water use of petunia.

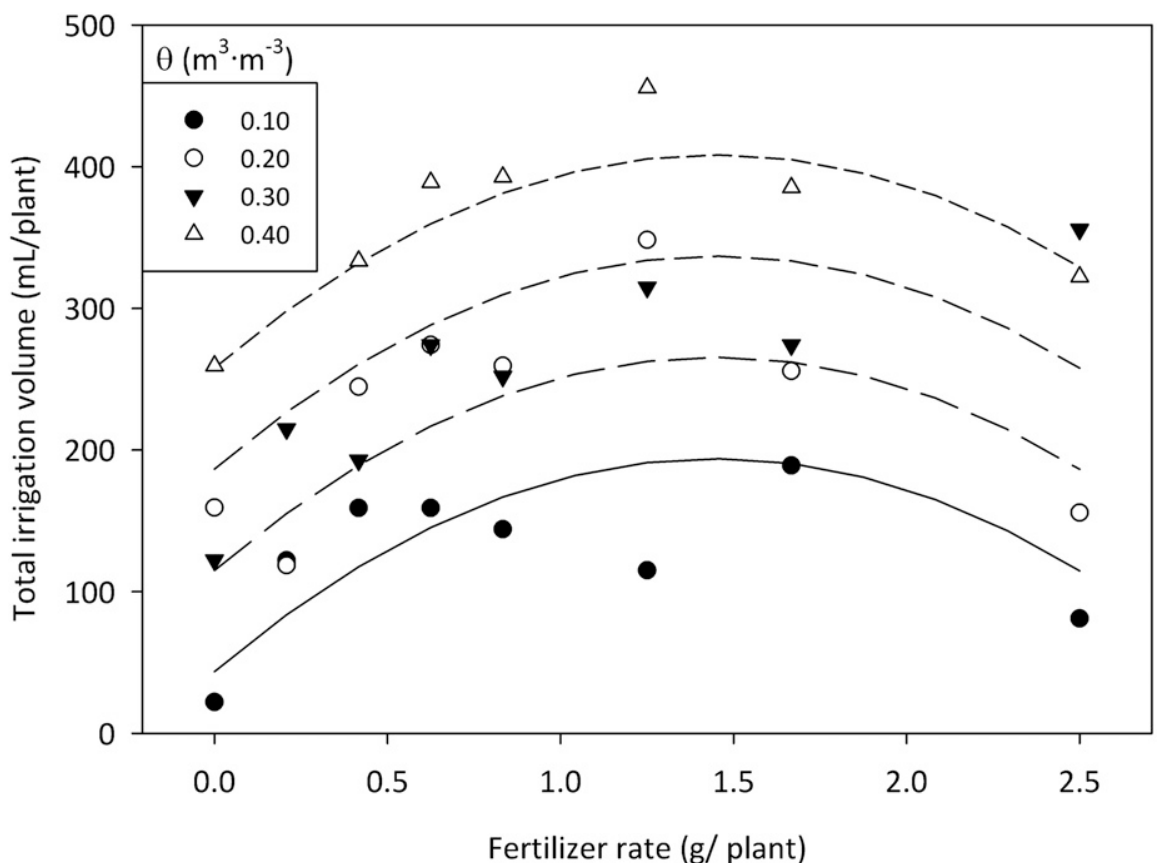

Fig. 5. The effect of controlled-release fertilizer rate and substrate water content $(\theta)$ on the total irrigation volume of petunias over a 23 -d growing period. There was a quadratic effect of fertilizer rate and a linear effect of $\theta$ on irrigation volume, but no interactive effect (see Table 2 for regression results).

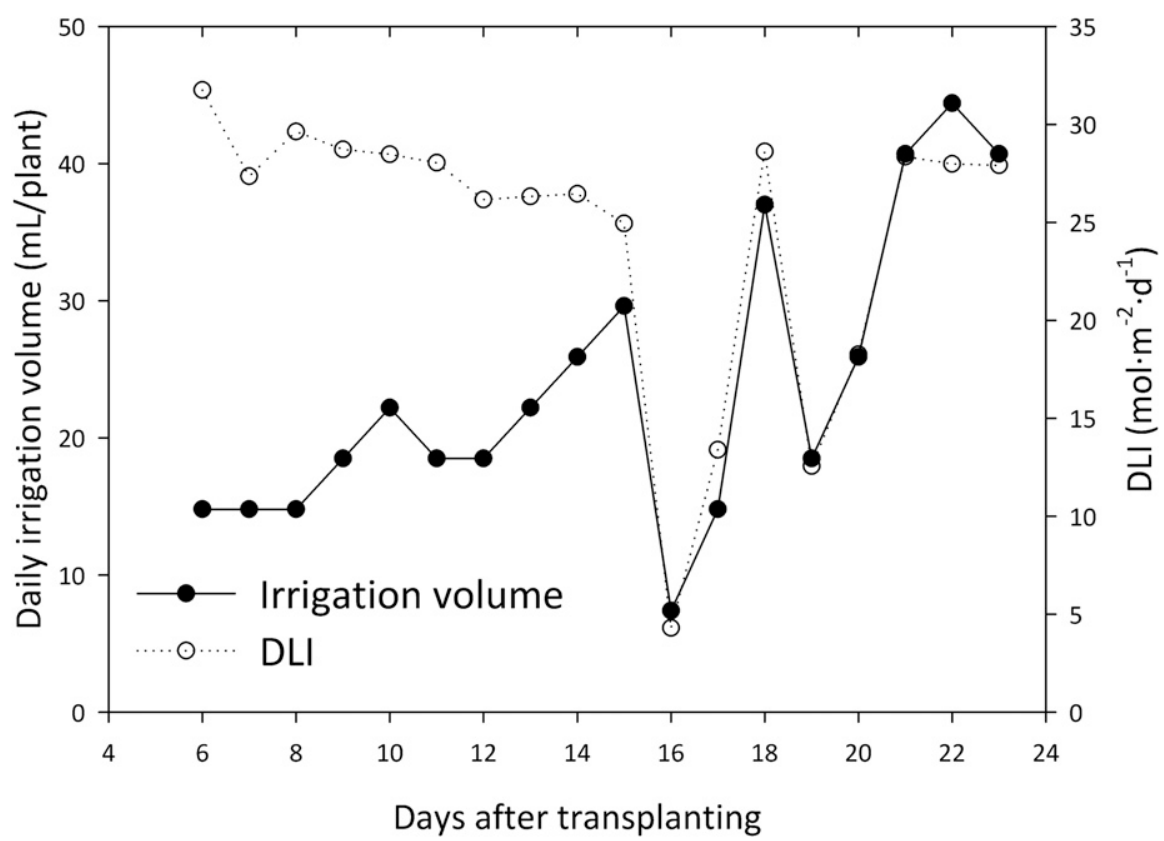

Fig. 6. The daily light integral (DLI) and daily irrigation volume of petunia over a 23 -d growing period. The plants were grown with a substrate water content $(\theta)$ threshold of $0.40 \mathrm{~m}^{3} \cdot \mathrm{m}^{-3}$ and a controlled-release fertilizer rate of $1.25 \mathrm{~g} /$ plant. Daily irrigation volume $=1.44+0.06569 \times$ day $\times$ DLI $\left(R^{2}=0.96\right.$, $P<0.0001)$

Other environmental variables such as temperature and VPD also can affect water use of ornamental greenhouse crops (Baille et al., 1994; Kim and van Iersel, 2009) but were not statistically significant in this study. However, we cannot rule out the possibility that these variables affected daily irrigation volume, because there were strong correlations between VPD and DLI ( $r=$ $0.92)$ and temperature and days after transplanting $(r=-0.90)$. Thus, it was difficult to distinguish between the effects of temperature and days after transplanting or of VPD and DLI.

Consistent with previous findings (Kim et al., 2011; van Iersel et al., 2010), shoot dry 
weight was strongly correlated with both total irrigation volume and total ET with slopes of 2.51 and $3.51 \mathrm{~g} \cdot \mathrm{L}^{-1}$, respectively (Fig. 7). The slope of the dry weight vs. irrigation volume was similar to previous findings (2.54 and $2.45 \mathrm{~g} \cdot \mathrm{L}^{-1}$; Kim et al., 2011; van Iersel et al., 2010). Although we have previously referred to the slope of this regression line as water use efficiency (Kim et al., 2011; van Iersel et al., 2010), this slope does not reflect water use efficiency in the traditional sense (dry weight produced per unit water applied). It does, for example, not take into account possible differences in water use efficiency among the treatments.

Flowering. Flowering is an important ornamental quality trait of petunia. Plants grown at lower CRF rates and $\theta$ thresholds
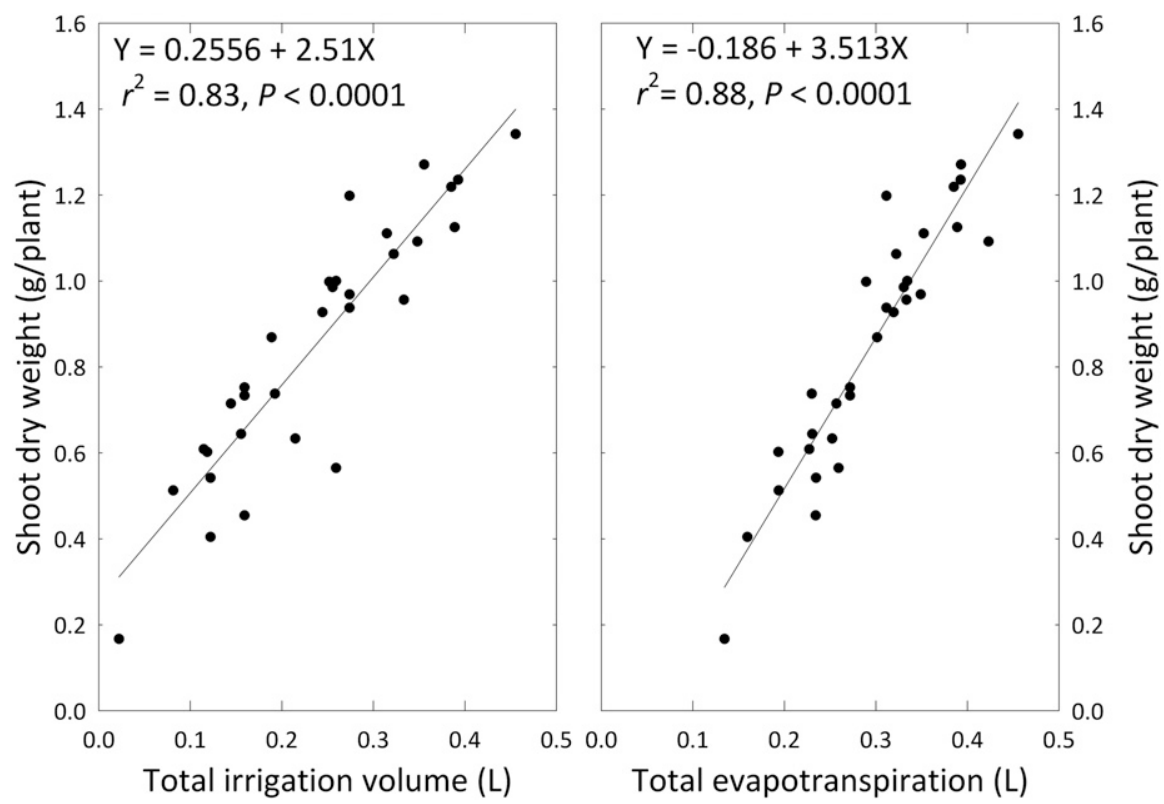

Fig. 7. The shoot dry weight as a function of total irrigation volume (left) and total evapotranspiration (right) from the start of the irrigation treatments to the end of the experiment $(23 \mathrm{~d})$.

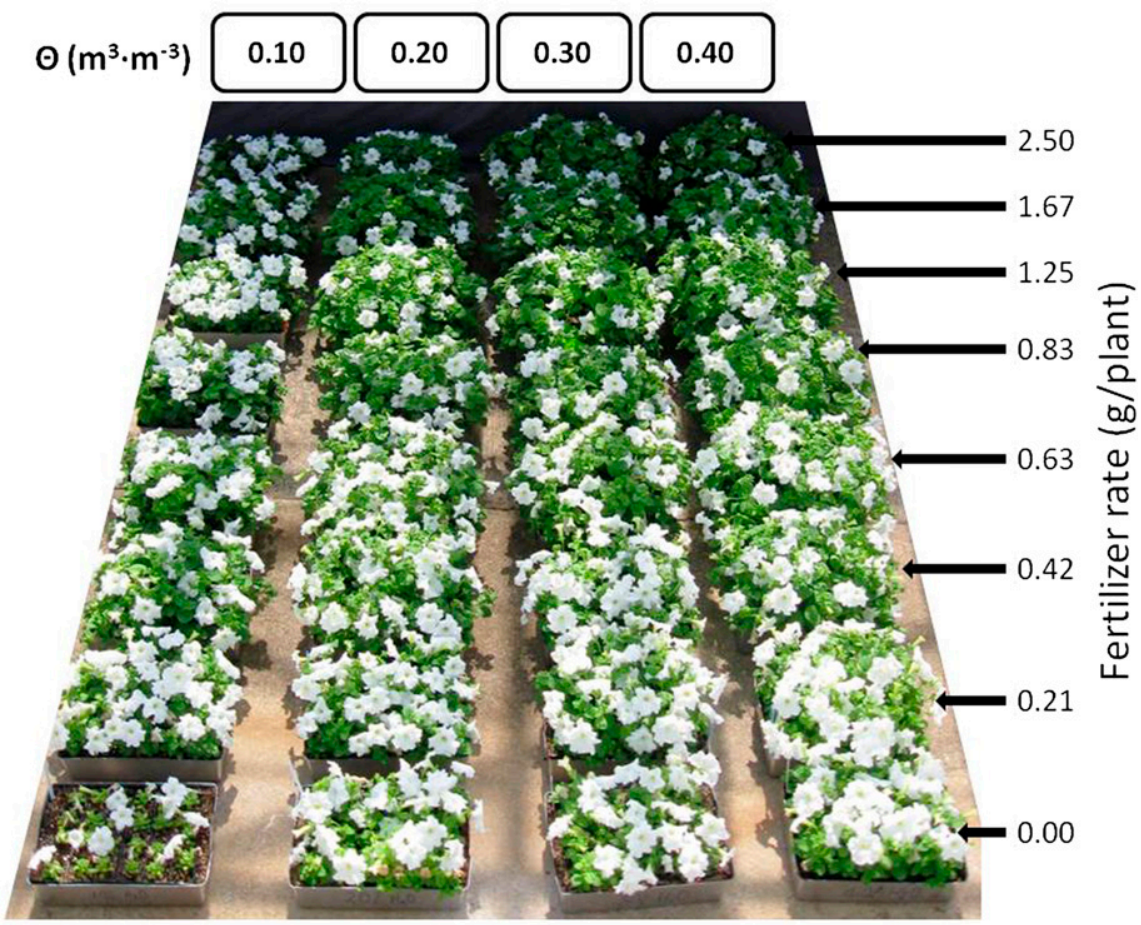

Fig. 8. Appearance of petunias at harvest (23 d after transplanting) as affected by the rate of controlledrelease fertilizer and substrate water content $(\theta)$. Flowering was reduced by the combination of high fertilizer rates $(>0.63 \mathrm{~g} / \mathrm{plant})$ and high $\theta\left(0.20\right.$ to $\left.0.40 \mathrm{~m}^{3} \cdot \mathrm{m}^{-3}\right)$.

had more flowers than those with the highest shoot dry weights and leaf areas (Fig. 8). Maximum shoot dry weight was achieved with 1.3 to $1.67 \mathrm{~g} /$ plant CRF and a $\theta$ threshold of $0.40 \mathrm{~m}^{3} \cdot \mathrm{m}^{-3}$ (Fig. 3), but maximum flowering occurred with the 0.21 to $0.63 \mathrm{~g} /$ plant CRF rates and $\theta$ thresholds of $0.20 \mathrm{~m}^{3} \mathrm{~m}^{-3}$. A similar relationship between flowering and fertilizer rate was described by James and van Iersel (2001); flowering of subirrigated petunia and wax begonia (Begonia $\times$ semperflorens) increased with an increase in fertilizer solution EC (from 0.15 to $1.8 \mathrm{dS} \cdot \mathrm{m}^{-1}$ ), whereas flower number decreased (begonia) or was similar (petunia) at even higher fertilizer solution EC. The CRF rates that produced maximum flowering $(0.21$ to $0.63 \mathrm{~g} / \mathrm{plant})$ were much lower than the commercially recommended rates (1.01 to $3.26 \mathrm{~g} / \mathrm{plant}$ ). The use of precision irrigation may have prevented nutrient leaching from the substrate, thus reducing the fertilizer requirements of the crop.

Leaf chlorophyll index. The average leaf chlorophyll index increased with an increase in CRF rate (partial $R^{2}=0.15$ ). However, the leaf chlorophyll index also decreased over time, but the decrease was dependent on CRF rate and $\theta$ thresholds (partial $R^{2}=$ 0.38 ). The chlorophyll index increased with increasing CRF rate at the $0.10 \mathrm{~m}^{3} \cdot \mathrm{m}^{-3} \theta$ threshold, but this response was less pronounced at higher $\theta$ thresholds and absent at $0.40 \mathrm{~m}^{3} \cdot \mathrm{m}^{-3}$ (Fig. 9). The leaf chlorophyll index is a common indicator of plant health and leaf nitrogen content (e.g., Yoder and Pettigrew-Crosby, 1995). The leaf chlorophyll index was correlated with shoot $\mathrm{N}(r=$ $0.54, P=0.0015), \mathrm{P}(r=0.49, P=0.0048)$, $\mathrm{K}(r=0.46, P=0.0086), \mathrm{S}(r=0.53, P=$ $0.0013)$, and $\mathrm{Zn}(r=0.40, P=0.023)$. Given the correlation of the leaf chlorophyll index with multiple nutrients, it is not clear which nutrient(s) were limiting the leaf chlorophyll index. However, given the typical nutrient deficiency symptoms of petunia (Pitchay et al., 2002), low chlorophyll levels were most likely caused by $\mathrm{N}$ and/or $\mathrm{S}$ deficiency.

\section{Conclusions}

The sensor-controlled irrigation system effectively maintained $\theta$ close to treatment threshold levels with little or no leaching. High-quality petunias were grown with CRF rates much lower than commercially recommended. Shoot dry weight increased with an increase in CRF rate, but the increase depended on $\theta$. Shoot dry weight of plants grown at higher $\theta$ thresholds responded more strongly to an increase in CRF rate. Leaf size also increased with increasing CRF rate and this effect was more pronounced at higher $\theta$ thresholds. However, lower CRF rates $(0.21$ to $0.63 \mathrm{~g} / \mathrm{plant}$ ) resulted in more flowers. Because vegetative growth responded differently to CRF and $\theta$ than flowering, growers can adjust fertilizer rates and $\theta$ to manipulate growth and development of petunia. 


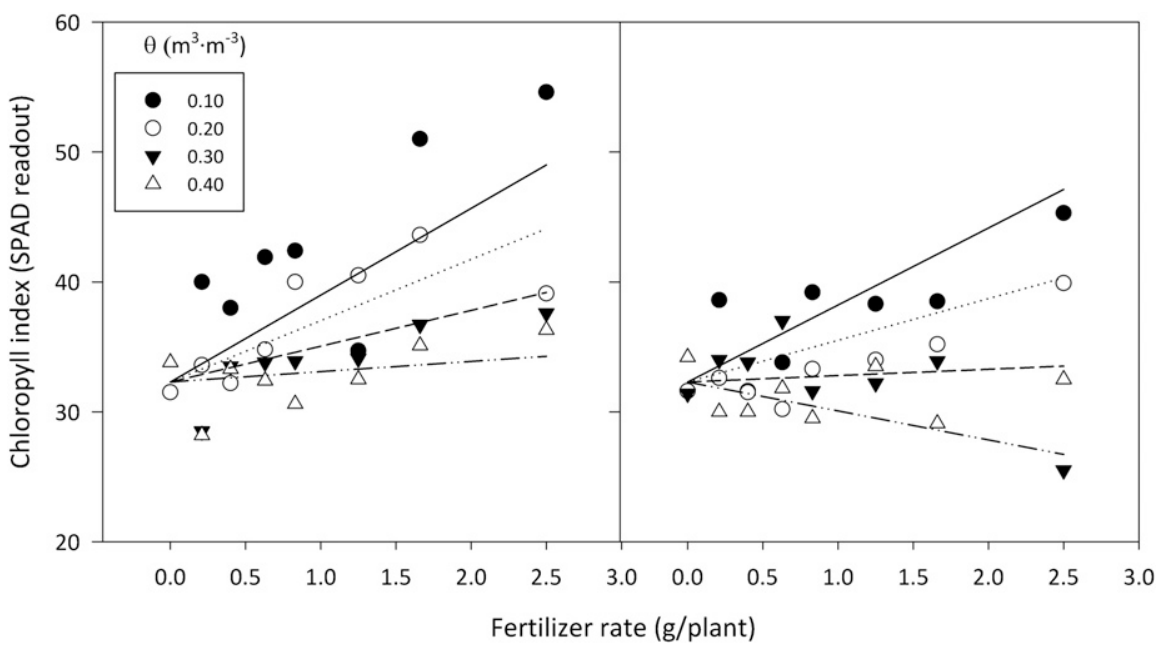

Fig. 9. The leaf chlorophyll index, as measured with a SPAD meter, of petunia measured on 13 (left) and 18 (right) days after transplanting as affected by controlled-release fertilizer rate, time (days after transplanting), and substrate water content $(\theta)$. Data were analyzed using multiple regression (chlorophyll index $=32.29+8.65 \times$ fertilizer rate $-1.511 \times$ day $\times \theta \times$ fertilizer rate; $R^{2}=0.53, P=$ $0.0003)$. The regression lines were calculated by inserting the specific values for measurement day and $\theta$ into the regression equation, resulting in separate lines for each day and fertilizer rate combination.

\section{Literature Cited}

Adams, C., J. Frantz, and B. Bugbee. 2013. Macro and micronutrient release characteristics of three polymer-coated fertilizers: Theory and measurements. J. Plant Nutr. Soil Sci. 176:76-88.

Alem, P.O., P.A. Thomas, and M.W. van Iersel. 2014. Irrigation volume and fertilizer concentration effects on leaching and growth of petunia. Acta Hort. 1034:143-148.

Baille, M., A. Baille, and J.C. Laury. 1994. A simplified model for predicting evapotranspiration rate of nine ornamental species vs. climate factors and leaf area. Sci. Hort. 59:217-232.

Bayer, A., K. Whitaker, M. Chappell, J. Ruter, and M. van Iersel. 2014. Effect of irrigation duration and fertilizer rate on plant growth, substrate solution EC, and leaching volume. Acta Hort. 1034:477-484.

Bilderback, T.E. 2002. Water management is key in reducing nutrient runoff from container nurseries. HortTechnology 12:541-544.

Birrenkott, B.A., J.L. Craig, and G.R. McVey. 2005. A leach collection system to track the release of nitrogen from controlled-release fertilizers in container ornamentals. HortScience 40:1887-1891.

Broschat, T.K. 1995. Nitrate, phosphate, and potassium leaching from container-grown plants fertilized by several methods. HortScience 30:74-77.

Broschat, T.K. 1996. Release rates of soluble and controlled release potassium fertilizers. HortTechnology 6:128-131.

Broschat, T.K. and K.A. Moore. 2007. Release rates of ammonium-nitrogen, nitrate-nitrogen, phosphorus, potassium, magnesium, iron, and manganese from seven controlled release fertilizers. Commun. Soil Sci. Plant Anal. 38:843-850.

Burnett, S.E. and M.W. van Iersel. 2008. Morphology and irrigation efficiency of Gaura lindheimeri grown with capacitance-sensor controlled irrigation. HortScience 43:1555-1560.

Cabrera, R.I. 2005. Challenges and advances in water and nutrient management in nursery and greenhouse crops. Agricoltura Mediterranea 135:147-160.

Chappell, M., S.K. Dove, M.W. van Iersel, P.A. Thomas, and J. Ruter. 2013. Implementation of wireless sensor networks for irrigation control
Hilhorst, M.A. 2000. A pore water conductivity sensor. Soil Sci. Soc. Amer. J. 64:1922-1925.

James, E.C. and M.W. van Iersel. 2001. Fertilizer concentration affects growth and flowering of sub-irrigated petunias and begonias. HortScience 36:40-44.

Kalapos, T., R. van den Boogaard, and H. Lambers. 1996. Effect of soil drying on growth, biomass allocation and leaf gas exchange of two annual grass species. Plant Soil 85:137-149.

Kang, J.G. and M.W. van Iersel. 2009. Managing fertilization of bedding plants: A comparison of constant fertilizer concentrations versus constant leachate electrical conductivity. HortScience 44:151-156.

Kim, J. and M.W. van Iersel. 2009. Daily water use of abutilon and lantana at various substrate water contents. Proc. SNA Res. Conf. $54: 12-16$.

Kim, J., M.W. van Iersel, and S.E. Burnett. 2011. Estimating daily water use of two petunia cultivars based on plant and environmental factors. HortScience 46:1287-1293.

Lea-Cox, J.D. and D.S. Ross. 2001. A review of the federal Clean Water Act and the Maryland Water Quality Improvement Act-The rationale for developing a water and nutrient management planning process for container nursery and greenhouse operations. J. Environ. Hort. 19:226-229.

in three container nurseries. HortTechnology 23:747-753.

Chen, J., Y. Huang, and R.D. Caldwell. 2001. Best management practices for minimizing nitrate leaching from container grown nurseries. Sci. World J. 1:96-102.

Cox, D.A. 1993. Reducing nitrogen leachinglosses from containerized plants: The effectiveness of controlled release fertilizers. J. Plant Nutr. 16:533-545.

Dole, J.M., J.C. Cole, and S.L. von Broembsen. 1994. Growth of poinsettias, nutrient leaching, and water use efficiency respond to irrigation methods. HortScience 29:858-864.

Du, C., J. Zhou, and A. Shaviv. 2006. Release characteristics of nutrients from polymercoated compound controlled release fertilizers. J. Polymer Environ. 14:223-230.

Fernandez, R.J., M. Wang, and J.F. Reynolds. 2002. Do morphological changes mediate plant responses to water stress? A steady-state experiment with two C4 grasses. New Phytol. 155:79-88.

Frett, J.J., M.A. Dirr, and A.M. Armitage. 1985. Nitrogen and calcium requirements of Petunia hybrida 'Coral Sea'. Sci. Hort. 26:351-359.

Garland, K.F., S.E. Burnett, M.E. Day, and M.W. van Iersel. 2012. Influence of substrate water content and daily light integral on photosynthesis, water use efficiency, and morphology of Heuchera americana. J. Amer. Soc. Hort. Sci. 137:57-62.

Groves, K.M., S.L. Warren, and T.E. Bilderback. 1998 Irrigation volume, application and controlledrelease fertilizers: I. Effect on plant growth and mineral nutrient content in containerized plant production. J. Environ. Hort. 16:176-181.

Haver, D.L. and U.K. Schuch. 1996. Production and postproduction performance of two New Guinea Impatiens cultivars grown with controlled release fertilizer and no leaching. J. Amer. Soc. Hort. Sci. 121:820-825.

Hershey, D.R. 1989. Improved equipment for vacuum extraction of saturated growing media. HortScience 24:155.

Hershey, D.R. and J.L. Paul. 1982. Leaching losses of nitrogen from pot chrysanthemums with controlled release or liquid fertilization. Sci. Hort. 17:145-152.
Lea-Cox, J.D., D.S. Ross, and K.M. Teffeau. 2001 A water and nutrient management planning process for container nursery and greenhouse production systems in Maryland. J. Environ. Hort. 19:230-236.

Majsztrik, J.C., A.G. Ristvey, and J.D. Lea-Cox. 2011. Water and nutrient management in the production of container-grown ornamentals. Hort. Rev. 38:253-296.

Merhaut, D.J., E.K. Blythe, J.P. Newman, and J.P. Albano. 2006. Nutrient release from controlledrelease fertilizer in acid substrate in a greenhouse environment: I. Leachate electrical conductivity, $\mathrm{pH}$, and nitrogen, phosphorus, and potassium concentrations. HortScience 41:780-787.

Mikkelsen, R.L., H.W. Williams, and A.D. Behel, Jr. 1994. Nitrogen leaching and plant uptake from controlled-release fertilizers. Fert. Res. $37: 43-50$.

Mills, H.A. and J.B. Jones. 1996. Plant analysis handbook II: A practical sampling, preparation, analysis, and interpretation guide. MicroMacro Publishing, Athens, GA.

Morgan, T. and D. Reed. 1998. Characterizing salinity limits of New Guinea impatiens in recirculating subirrigation. HortScience 123:156-160.

Nemali, K.S., F. Montesano, S.K. Dove, and M.W. van Iersel. 2007. Calibration and performance of moisture sensors in soilless substrates: $\mathrm{ECH}_{2} \mathrm{O}$ and Theta probes. Sci. Hort. 112:227-234.

Nemali, K.S. and M.W. van Iersel. 2006. An automated system for controlling drought stress and irrigation in potted plants. Sci. Hort. 110:292297.

Nye, P.R. and P.B. Tinker. 1977. Solute movement in the soil root system. Blackwell Sci., Oxford, UK.

O’Meara, L., M.W. van Iersel, and M.R. Chappell. 2013. Daily water use of Hydrangea macrophylla and Gardenia jasminoides as affected by growth stage and environmental conditions. HortScience 48:1040-1046.

Pitchay, D.S., A.L. Williams, J.L. Gibson, B.E. Whipker, P.V. Nelson, J.M. Dole, B.R. Cleveland, and F.R. Wall. 2002. Nutrient deficiencies of vegetative petunia. $10 \mathrm{Dec}$. 2014. <http://www.ces.ncsu.edu/depts/hort/ floriculture/def/petunia.htm>. 
Plaut, Z., N. Zieslin, and I. Arnon. 1973. The influence of moisture regime on greenhouse rose production in various growth media. Sci. Hort. 1:239-250.

Ristvey, A.G., J.D. Lea-Cox, and D.S. Ross. 2001. Nitrogen uptake, partitioning and loss in container production systems. Proc. South. Nurs. Assoc. Res. Conf. 46:101-107.

Rouphael, Y., M. Cardarelli, E. Rea, and G. Colla. 2008. The influence of irrigation system and nutrient solution concentration on potted geranium production under various conditions of radiation and temperature. Sci. Hort. 118:328-337.

Scoggins, H.L. and M.W. van Iersel. 2006. In situ probes for measurement of electrical conductivity of soilless substrates: Effects of temperature and substrate moisture content. HortScience 40:210-214.

Shaviv, A. and R. Mikkelsen. 1993. Controlledrelease fertilizers to increase efficiency of nutrient use and minimize environmental degradation: A review. Fert. Res. 35:1-12.

Taylor, R.D., B.W.W. Grout, and J. Hill. 2004. Use of a tensiometer-based control system to reduce irrigation of cut flower Dianthus caryophyllus 'Santorini' whilst maintaining flower yield and quality. Acta Hort. 664: 647-652.

van Iersel, M.W., S. Dove, J.G. Kang, and S.E. Burnett. 2010. Growth and water use of petunia as affected by substrate water content and daily light integral. HortScience 45:277-282.

van Iersel, M.W., P.A. Thomas, R.B. Beverly, J.G. Latimer, and H.A. Mills. 1998. Nutrition affects pre- and post-transplant growth of impatiens and petunia plugs. HortScience 33:1014-1018.

Yoder, B.J. and R.E. Pettigrew-Crosby. 1995. Predicting nitrogen and chlorophyll content and concentrations from reflectance spectra (400 $2500 \mathrm{~nm}$ ) at leaf and canopy scales. Remote Sens. Environ. 53:199-211.

Zheng, Y., T. Graham, S. Richard, and M. Dixon. 2004. Potted gerbera production in a subirrigation system using low-concentration nutrient solutions. HortScience 39:1283-1286. 